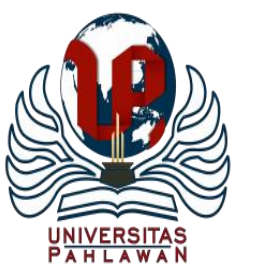

Jurnal Basicedu Volume 4 Nomor 4 Tahun 2020 Halm. 938 - 946

JURNAL BASICEDU

Research \& Learning in Elementary Education

https://jbasic.org/index.php/basicedu/index

\title{
Pengembangan Multimedia Interaktif Berbasis Model Problem Based Learning (PBL) Bagi Siswa Sekolah Dasar
}

\author{
Rahmadani $^{1}$ Taufina $^{2}$ \\ Universitas Negeri Padang, Sumatera Barat, Indonesia ${ }^{1,2}$ \\ E-mail : $\underline{\text { ani3239@gmail.com }} \underline{\text { taufina @ fip.unp.ac.id }}^{2}$
}

\begin{abstract}
Abstrak
Penelitian ini merupakan penelitian pengemabangan yang bertujuan menghasilkan CD Multimedia Interaktif berbasis model PBL yang dapat digunakan siswa kelas V SD Islam YAAK Ampang Kuranji, Kabupaten Dharmasraya sebagai media pembelajaran. Mengetahui kualitas dari CD multimedia interaktif berbasis model PBL tersebut dilakukan uji validitas, pratikalitas, dan efektifitas. Berdasarkan uji validitas penilaian yangdilakukan oleh ahli media, ahli materi dan pembelajaran, model pengembangan yang digunakan adalah 4D terdiri atas 4 tahap utama yaitu, define (pembatas), design (perancangan), develop (pengembangan) dan disseminate (penyebaran). Pengembangan $\mathrm{CD}$ multimedia ini dimulai dengan cara analisis kebutuhan siswa, analisis standar isi dilanjutkan dengan pengumpulan referensi media kemudian penyusunan rancangan media, dan membuat CD multimedia interaktif. Multimedia interaktif yang telah dibuat dikonsultasikan dan dinilaikan kepada para pakar yaitu ahli materi pembelajaran, ahli media, ahli bahasa, dan siswa kelas besar.
\end{abstract}

Kata kunci: CD multimedia interaktif, model pembelajaran PBL, media pembelajaran

Abstract

This research is a research development that aims to produce a CD Multimedia interactive based on the model PBL which can be used by students of grade V SD Islam YAAK Ampang Kuranji, Dharmasraya Regency as a learning media. Knowing the quality of the CD interactive multimedia based on the PBL model is carried out test of validity, pratikality, and effectiveness. Based on a validity test of the assessment conducted by the media experts, materials and learning experts, the development Model used is $4 D$ consists of 4 main phases, Define (limiter), Design (design), Develop (development) and Disseminate (dissemination). CD Multimedia Development began with the analysis of students ' needs, standard analysis of Isi followed by the collection of media reference then the preparation of media design, and create CD Multimedia interactive. Interactive Multimedia that has been created is consulted for experts who are experts in learning materials, media experts, linguists, and large-class students.

Keywords: interactive multimedia CD, PBL learning Model, integrated media learning thematic

Copyright (C) 2020 Rahmadani, Taufina

$\triangle$ Corresponding author :

Address : Universitas Negeri Padang

Email : ani3239@gmail.com

ISSN 2580-3735 (Media Cetak)

Phone :

ISSN 2580-1147 (Media Online)

DOI : https://doi.org/10.31004/basicedu.v4i4.465 


\section{PENDAHULUAN}

Pembelajaran merupakan suatu proses interaksi antara peserta didik dengan pendidik dan sumber belajar. Dalam proses pembelajaran, pendidik harus memiliki strategi agar peserta didik dapat mencapai tujuan dalam mendapatkan hasil pembelajaran yang optimal, sehingga penerapan pendidikan harus diselenggarakan sesuai dengan Sistem Pendidikan Nasional. Salah satu strategi yang dapat digunakan adalah memanfaatkan sarana dan prasarana dalam pendidikan, dengan pemanfaatan sarana prasarana tersebut akan membuat pembelajaran berlangsung dengan baik sesuai dengan proses yang diharapkan dan dapat memenuhi standar yang telah ditetapkan. Pelaksanaan pembelajaran di kelas idealnya harus jauh lebih baik lagi, apalagi dengan adanya perkembangan kurikulum 2013 yang terintegrasi pada teknologi. Banyak penelitian yang telah dilakukan untuk meningkatkan keterampilan membaca siswa sekolah dasar yaitu dengan menggunakan strategi, model dan, metode membaca penelitian, meningkatkan membaca pemahaman menggunakan metode Genering Interacting Schemata and Text (GIST) di sekolah dasar (Taufik Taufina \& Arwin, 2018). Peningkatan keterampilan membaca pemahaman dengan menggunakan Takling Stick di kelas IV SDN 37 Koto Pulai Penelitian (Taufik Taufina \& Arwin, 2018). Efektivitas strategi Reciprocal Teaching dan KWL terhadap keterampilan membaca pemahaman siswa sekolah dasar (Taufik Taufina \& Arwin, 2018). Hasil penelitian pada umumnya menunjukkan bahwa penggunaan strategi, model, dan metode membaca dapat meningkat keterampilan membaca siswa sekolah dasar.

Perkembangan teknologi dalam pembelajaran sekarang ini memungkinkan peserta didik untuk akses terhadap sumber-sumber belajar yang sifatnya terbuka dan menggambarkan kondisi dunia nyata yang tidak hanya melibatkan peserta didik dengan lingkungan saja, akan tetapi dalam kegiatan pembelajaran juga dapat memanfaatkan komputer untuk membuat dan mengembangkan teks, grafik, audio, gambar bergerak (video dan animasi) dengan menggabungkan link dan tool yang memungkinkan pemakaian untuk melakukan navigasi, berinteraksi,berkreasi dan berkomunikasi (Taufik Taufina \& Arwin, 2018).

Permasalahan lain yang ditemukan dalam proses pembelajaran dari segi siswa adalah:(1) siswa kurang aktif dan banyak diam saat aktivitas belajar, (2) siswa kurang dimotivasi dan tidak bekerja sesuai dengan keinginan sendiri, (3) siswa kurang menguasai konsep materi yang dipelajarinya, (4) siswa tidak memberikan respon balik saat proses pembelajaran.

Berdasarkan informasi yang diperoleh, faktor penyebab munculnya permasalahan dikarenakan guru kurang menggunakan media pembelajaran interaktif yang berintegrasi pada kecanggihan teknologi yang dapat mendukung proses pembelajaran. Selain itu, guru kurang memberikan kesempatan pada siswa untuk melakukan pembelajaran mandiri dimulai dari pengamatan terhadap suatu permasalahan, melatih siswa untuk menganalisis, eksperimen, mengolah informasi, melakukan kalaboratif, menyimpulkan 
dan mengkomunikasikan dari suatu benda atau objek kejadian.

Menjawab persoalan diatas, maka perlu adanya media pembelajaran CD Multimedia Interaktif berbasis Model Problem Based Learning (PBL) sebagai media pembelajaran instruksional modern yang sesuai dengan perkembangan zaman (kemajuan IPTEK) meliputi media yang dapat dilihat dan didengar dan dalam mengaplikasikannya di kelas. Model pembelajaran PBL merupakan model pembelajaran yang menyediakan pengalaman otentik yang mendorong peserta didik untuk belajar aktif, dimana dalam prakteknya peserta didik terlibat langsung dalam memecahkan suatu masalah sehingga mampu mendorong peserta didik untuk berfikir secara kritis yang nantinya dapat melatih peserta didik untuk menyelesaikan suatu permasalahan dengan mandiri. (Taufik Taufina \& Arwin, 2018). Keberhasilan penggunaan model PBL dalam pembelajaran sekolah dasar telah dibuktikan melalui penelitian pengembangan bahan ajar tematik terpadu dengan model problem based learning di kelas V SD (Taufik Taufina \& Arwin, 2018). Peningkatan proses pembelajaran tematik terpadu menggunakan model problem based learning pada kelas $\mathrm{V}$ sekolah dasar (Taufik Taufina \& Arwin, 2018). Hasil penelitian menunjukkan peningkatan hasil belajar siswa menggunakan model pembelajaran PBL. Peningkatan hasil belajar pembelajaran tematik terpadu menggunakan model PBL di Kelas V Sekolah Dasar (Taufik Taufina \& Arwin, 2018). Hasil penelitian menunjukkan model pembelajaran berdasarkan masalah dapat meningkatkan proses pembelajaran tematik yang terintegrasi.

Model Problem Based Learning merupakan suatu model pembelajaran yang menggunakan masalah yang ada di sekitar peserta didik sebagai awal dari proses pembelajaran, kemudian masalah tersebut dianalisis oleh peserta didik dalam berkelompok, agar dapat melatih peserta didik untuk berfikir kritis dan memiliki keterampilan untuk memecahkan masalah sehingga peserta didik dapat memperoleh pemahaman tentang materi pelajaran dan kemampuan sosial peserta didik juga dapat dikembangkan menyeluruh dalam pembelajaran tematik terpadu di sekolah dasar.

Berdasarkan penelitian yang telah dilakukan sebelumnya, peneliti merasa perlu lebih mengembangkan penelitian mengenai $\mathrm{CD}$ Multimedia Interaktif berbasis PBL yang valid, praktis dan efektif pada pembelajaran tematik terpadu kelas V SD Islam Modern YAAK Dharmasraya.

\section{METODE}

Jenis penelitian ini adalah pengembangan yang mengacu pada model 4D, model ini dikembangkan oleh S. Thiagarajan, (Taufik Taufina \& Arwin, 2018) menjelaskan tahap-tahap model 4-D antara lain: pendefinisian (define), perancangan (design), pengembangan (develop), dan penyebaran (disseminate). Akan tetapi, karena keterbatasan tenaga, biaya, dan waktu penulis, tahap penyebaran (disseminate) hanya dilakukan pada skala terbatas yaitu kelas IV Sekolah Dasar sesuai dengan kebutuhan penulis. 
Pada tahap pertama ,pendefinisian dilakukan analisis kurikulum, analisis kebutuhan serta analisis peserta didik. Tahap kedua, perancangan dilakukan perancangan bahan ajar sesuai dengan Kompetensi Inti (KI) dan Kompetensi Dasar (KD) serta kesesuaian materi dengan kurikulum yang berlaku, kemudian memilih sumber belajar, menentukan urutan proses pembelajaran sesuai dengan strategi pembelajaran kooperatif tipe round table serta tata bahasa yang digunakan. Tahap ketiga, pengembangan dilakukan validasi oleh validator sebagai ahli dalam memvalidasi bahan ajar yang telah dirancang, revisi jika perlu adanya perbaikan terhadap bahan ajar yang dirancang dan tahap uji coba produk atau bahan ajar setekah dilakukannya revisi yang disarankan oleh validator. Tahap uji coba ini juga bermanfaat untuk mengetahui praktikalitas dan efektifitas dari bahan ajar yang dirancang. Tahap keempat, yaitu penyebaran bahan ajar, yang dilakukan dikelas $\mathrm{V}$ Sekolah Dasar (SD).

\section{HASIL DAN PEMBAHASAN}

Bahan ajar merupakan sebuah sumber materi pembelajaran yang digunakan guru pada saat proses pembelajaran untuk memfokuskan tujuan materi pembelajaran yang akan dibahas sesuai dengan indikator pembelajaran yang ingin dicapai oleh guru. Bahan ajar memiliki komponenkomponen tertentu yang saling terkait satu sama lain. Seperti yang diterangkan oleh Hamdani (2011:122) yaitu beberapa komponen yang terdapat pada suatu bahan ajar di antaranya: a) judul, mata pelajaran, standar kompetensi, kompetensi dasar, indikator, dan tujuan pembelajaran, b) petunjuk belajar (petunjuk siswa dan guru), berisi tentang penjelasan cara penggunaan suatu bahan ajar yang akan dipelajari dalam sebuah proses pembelajaran, c) informasi pendukung, d) lembar kerja, dan f) evaluasi.

Menurut Abdul (2006) juga mengemukakan "sebuah bahan ajar paling tidak mencakup antara lain: 1) kompetensi yang akan dicapai, 2) petunjuk belajar (petunjuk guru dan siswa), informasi pendukung, dan evaluasi”. Sedangkan menurut (Taufik Taufina \& Arwin, 2018) menjelaskan bahwa komponen bahan ajar terdiri atas (1) identitas mata pelajaran, meliputi judul, materi, kompetensi, indikator, tujuan (2) petunjuk belajar, meliputi petunjuk untuk peserta didik dan guru, (3) isi materi pembelajaran, (4) informasi pendukung, (5) latihan-latihan, lembar kerja, (6) penilaian, (7) respon/balikan/refleksi.

Media pembelajaran multimedia interaktif yang sudah direvisi (Tabel 1) diserahkan kembali kepada validator. Validator diminta untuk memberikan penilaian dan pendapat terhadap bahan ajar multimedia interaktif yang sudah dirancang. Validasi selesai apabila validator sudah menyatakan bahwa bahan ajar yang dirancang sudah valid dan siap untuk diujicobakan. Validasi bahan ajar dilakukan terhadap beberapa aspek yang meliputi aspek kelayakan isi, aspek kebahasaan, aspek penyajian, dan aspek kegrafikaan. 
Tabel 1. Hasil Revisi Multimedia Interaktif pada Pembelajaran Tematik Terpadu dengan Model PBL di Kelas V SD

\begin{tabular}{|ll|ll|}
\hline \multicolumn{2}{|c|}{ Multimedia Pembelajaran Interaktif yang dikembangkan } \\
\hline \multicolumn{2}{|c|}{\begin{tabular}{c}
\multicolumn{1}{|c|}{ Sesudah Revisi } \\
\hline 1.
\end{tabular}} & $\begin{array}{l}\text { Penulisan kata benda, kata hubung, kata sifat, tanda baca masih } \\
\text { salah }\end{array}$ & 1. Penulisan sudah diperbaiki sesuai saran \\
\hline 2. & $\begin{array}{l}\text { Tambah tugas atau kegiatan yang akan dilakukan siswa } \\
\text { berkelompok }\end{array}$ & $\begin{array}{l}\text { Kegiatan sudah ditambahkan dengan tugas yang } \\
\text { dikerjakan dengan berdiskusi kelompok }\end{array}$ \\
\hline 3. & $\begin{array}{l}\text { Penggunaan warna merah dan kuning dibatasi karna dapat membuat } \\
\text { mata siswa lelah }\end{array}$ & 4. $\begin{array}{l}\text { Warna sudah diganti dengan warna yang lebih } \\
\text { lembut }\end{array}$ \\
\hline 5. & Font huruf masih ada di bawah 12 & 5. Font huruf sudah diatas 12 \\
\hline 6. & Sumber gambar tidak dicantumkan & 6. Sumber gambar sudah dicantumkan. \\
\hline
\end{tabular}

Tabel 2. Hasil Validasi Bahan Ajar Multimedia Interaktif Aspek Kelayakan Isi

\begin{tabular}{|c|c|c|c|}
\hline No. & Aspek yang Dinilai & Rata-rata & Kategori \\
\hline 1. & $\begin{array}{l}\text { Multimedia Interaktif mengacu pada kurikulum 2013, KI, KD } \\
\text { dan indicator. }\end{array}$ & 3.8 & Sangat Valid \\
\hline 2. & $\begin{array}{l}\text { Multimedia Interaktif menydiakan materi pembelajara yang } \\
\text { memuat penjelasan, contoh untuk menunjang pemahaman } \\
\text { konsep. }\end{array}$ & 3.6 & Sangat Valid \\
\hline 3. & $\begin{array}{l}\text { Multimedia Interaktif memuat media pembelajaran yang } \\
\text { berisikan materi yang sesuai dengan kebutuhan bahan ajar }\end{array}$ & 3.4 & Valid \\
\hline 4. & $\begin{array}{l}\text { Materi yang ada Multimedia Interaktif menyediakan } \\
\text { tugas/kegiatan }\end{array}$ & 3.8 & Sangat Valid \\
\hline 5. & Penjelasan materi dipertegas dengan gambar dan video & 3.4 & Valid \\
\hline 6. & Materi dapat meningkatkan kualitas pembelajaran & 3.8 & Sangat Valid \\
\hline \multicolumn{2}{|c|}{ Rata-rata } & 3,7 & Sangat Valid \\
\hline
\end{tabular}

Tabel 3. Hasil Validasi Multimedia Interaktif Aspek Kebahasaan

\begin{tabular}{|c|c|c|c|}
\hline No & Aspek yang Dinilai & Rata-rata & Kategori \\
\hline 1. & Keterbacaan & 3.8 & Sangat Valid \\
\hline 2. & Kejelasan informasi & 4 & Sangat Valid \\
\hline 3. & Kesesuaian dengan kaidah bahasa Indonesia yang baik dan benar & 3.2 & Valid \\
\hline 4. & Pemanfaatan bahasa secara efektif dan efisien (jelas dan singkat) & 3.8 & Sangat Valid \\
\hline \multicolumn{2}{|c|}{$\begin{array}{r}\text { Rata-rata } \\
\end{array}$} & 3,7 & Sangat Valid \\
\hline
\end{tabular}

Tabel 4. Hasil Validasi Multimedia Interaktif Secara Keseluruhan

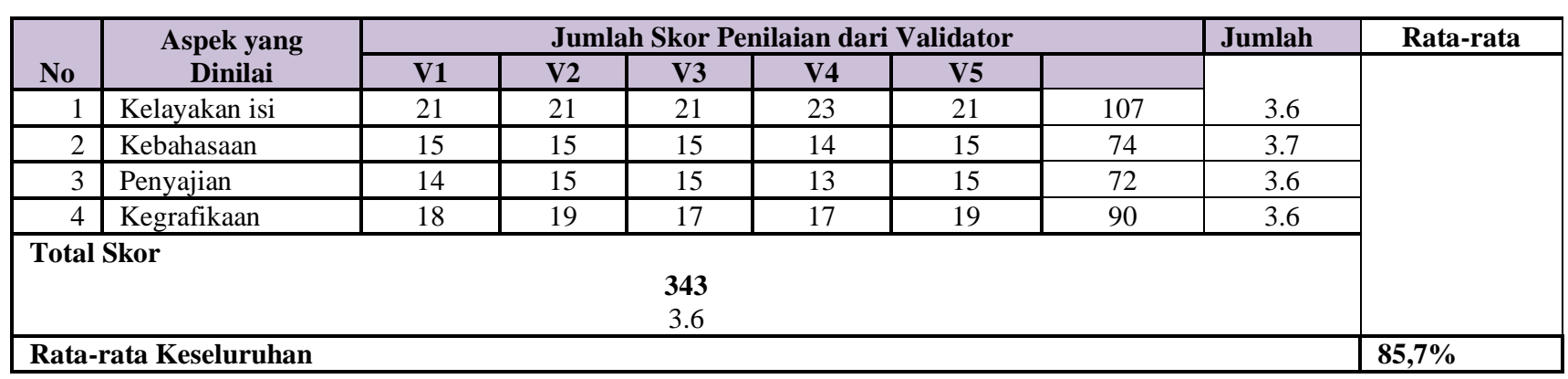


Berdasarkan sajian data pada tabel terlihat bahwa nilai rata-rata untuk setiap pernyataan berkisar antara 3,0 s/d 4,0 yang berada pada kategori valid hingga sangat valid. Untuk rata-rata validitas keseluruhan pada aspek kelayakan isi ini adalah 3,7 dengan kategori sangat valid. Ini berarti, isi bahan ajar telah menunjukkan kesesuaian antara isi dengan $\mathrm{KI}$ dan $\mathrm{KD}$, perkembangan siswa, kebutuhan bahan ajar, kebenaran substansi materi, dan telah memberikan penambah wawasan kepada siswa dan sesuai dengan nilai moral dan sosial.

Tabel menunjukkan bahwa setiap pernyataan pada aspek penilaian mempunyai rentang nilai antara 3,0 s/d 4,0 yang berada pada kategori valid hingga sangat valid. Sedangkan untuk rata-rata validitas aspek kebahasaan secara keseluruhan adalah 3,7 dengan kategori sangat valid. Dengan demikian, bahasa yang digunakan pada multimedia interaktif telah sesuai dengan kaidah bahasa Indonesia yang baik dan benar, mudah dipahami, jelas, dan singkat.

Data di atas menunjukkan nilai rata-rata skor keseluruhan validasi multimedia interaktif dengan total skor $85,7 \%$ dengan kategori sangat valid. Jadi dapat disimpullkan bahwa bahan ajar multimedia interaktif pada pembelajaran tematik terpadu berbasis model problem based learning (PBL) di kelas V Sekolah Dasar telah valid dengan kategori sangat baik.
Tabel 5. Analisis Respon Siswa Persentase Hasil Penyebaran Angket Respon Siswa

\begin{tabular}{|c|c|c|c|}
\hline No. & Aspek yang Dinilai & $\begin{array}{l}\text { Tingkat } \\
\text { Praktis }\end{array}$ & Kategori \\
\hline 1 & $\begin{array}{l}\text { Tampilan bahan ajar } \\
\text { multimedia interaktif } \\
\text { menarik perhatian } \\
\text { siswa }\end{array}$ & 3.5 & $\begin{array}{l}\text { Sangat } \\
\text { Praktis }\end{array}$ \\
\hline 2 & $\begin{array}{l}\text { Multimedia } \\
\text { Interaktif memiliki } \\
\text { warna yang menarik }\end{array}$ & 3.6 & $\begin{array}{l}\text { Sangat } \\
\text { Praktis }\end{array}$ \\
\hline 3 & $\begin{array}{lr}\text { Materi pembelajaran } \\
\text { pada multimedia } \\
\text { interaktif memiliki } \\
\text { keterkaitan dengan } \\
\begin{array}{lr}\text { kehidupan } \\
\text { hari }\end{array} & \text { sehari- } \\
\end{array}$ & 3.5 & $\begin{array}{l}\text { Sangat } \\
\text { Praktis }\end{array}$ \\
\hline 4 & $\begin{array}{l}\text { Petunjuk pada } \\
\text { multimedia interaktif } \\
\text { dapat dipahami } \\
\text { dengan mudah }\end{array}$ & 3.5 & $\begin{array}{l}\text { Sangat } \\
\text { Praktis }\end{array}$ \\
\hline 5 & $\begin{array}{l}\text { Siswa berpartisipasi } \\
\text { aktif dalam } \\
\text { penggunaan } \\
\text { multimedia interaktif } \\
\text { sehingga aktivitas } \\
\text { belajar meningkat }\end{array}$ & 3.6 & $\begin{array}{l}\text { Sangat } \\
\text { Praktis }\end{array}$ \\
\hline 6 & $\begin{array}{lr}\text { Gambar } & \text { yang } \\
\text { disajikan } & \text { pada } \\
\text { multimedia interaktif } & \\
\text { memperjelas } & \text { konsep } \\
\text { materi pembelajaran }\end{array}$ & 3.8 & $\begin{array}{l}\text { Sangat } \\
\text { Praktis }\end{array}$ \\
\hline 7 & $\begin{array}{l}\text { Materi ajar pada } \\
\text { media pembelajarn } \\
\text { multimedia interaktif } \\
\text { mudah dipahami }\end{array}$ & 3.6 & $\begin{array}{l}\text { Sangat } \\
\text { Praktis }\end{array}$ \\
\hline 8 & $\begin{array}{l}\text { Video animasi pada } \\
\text { media pembelajaran } \\
\text { multimedia interaktif } \\
\text { memperjelas materi } \\
\text { pelajaran }\end{array}$ & 3.8 & $\begin{array}{l}\text { Sangat } \\
\text { Praktis }\end{array}$ \\
\hline 9 & $\begin{array}{lr}\text { Penggunaan } & \text { bahan } \\
\text { ajar multimedia } & \text { sesuai } \\
\text { Interaktif } & \text { sesus } \\
\text { dengan } & \text { alokasi } \\
\text { waktu } & \text { yang } \\
\text { ditetapkan } & \\
\end{array}$ & 3.6 & $\begin{array}{l}\text { Sangat } \\
\text { Praktis }\end{array}$ \\
\hline 10 & $\begin{array}{l}\text { Latihan pada } \\
\text { tampilan multimedia } \\
\text { intteraktif membantu } \\
\text { siswa untuk } \\
\text { memahami konsep }\end{array}$ & 3.8 & $\begin{array}{l}\text { Sangat } \\
\text { Praktis }\end{array}$ \\
\hline & Jumlah & & \\
\hline & Rata-rata & & \\
\hline \multicolumn{2}{|c|}{ Tingkat kepraktisan } & \multicolumn{2}{|c|}{ Praktis } \\
\hline
\end{tabular}


Berdasarkan tabel terlihat bahwa setiap pernyataan yang menggambarkan kepraktisan menunjukkan tingkat kepraktisan yang berada pada rentang 3,5-4,0 yang termasuk ke dalam kategori sangat praktis. Dengan demikian diperoleh persentase kepraktisan dari hasil angket respon siswa adalah 3,7 Ini artinya multimedia interaktif berbasis model PBL pada pembelajaran tematik terpadu di kelas $\mathrm{V}$ sekolah dasar dapat dikategorikan sangat praktis.

Berdasarkan paparan di atas, bahan ajar memuat judul, mata pelajaran, kompetensi inti, kompetensi dasar, indikator, tujuan pembelajaran, petunjuk belajar (petunjuk guru dan peserta didik), berisi tentang penjelasan cara penggunaan suatu bahan ajar yang akan dipelajari dalam sebuah proses pembelajaran, informasi pendukung, lembar kerja, dan evaluasi. Bahan ajar yang digunakan oleh guru disesuaikan dengan kurikulum yang berlaku dimana kurikulum yang berlaku pada saat ini adalah kurikulum 2013.

Kurikulum 2013 adalah kurikulum dengan bentuk pembelajaran tematik integratif. Pembelajaran tematik integratif merupakan pembelajaran yang mengaitkan materi mata pelajaran dalam satu tema dalam satu kali pertemuan sehingga dapat memberikan pengalaman bermakna bagi peserta didik.

Belajar dengan menggunakan media $\mathrm{CD}$ Multimedia Interaktif berbasis PBL bukan hanya sekedar mendengarkan dan membaca, tetapi belajar dengan melibatkan pengalaman secara langsung antara tiap siswa dengan komputer. Melalui proses pengalaman ini diharapkan perkembangan peserta didik terjadi secara utuh yang tidak hanya berkembang secara kognitif saja, tetapi juga aspek afektif dan psikomotor. Hal ini dibuktikan dengan adanya penelitian yang pernah dilakukan oleh, (Sholikhah, dkk. 2017) penelitian ini di lakukan kepada siswa kelas 3 SD Negeri Karangasem, Kabupaten Karangasem Profinsi Bali. Penelitian (Taufik Taufina \& Arwin, 2018) penelitian ini dilakukan kepada siswa kelas VA SD Negeri Padangsambian, Kecamatan Denpasar Barat. Penelitian, (Taufik Taufina \& Arwin, 2018) penelitian ini dilakukan kepada siswa kelas 3 SD Negeri Tunggulsari II No 179, Kecamatan Laweyan, kota Surakarta, Provinsi Jawa Tengah. Dari penelitian tersebut terlihat keberhasilan belajar peserta didik dipengaruhi oleh media pembelajaran berbasis teknoligi yaitu Multimedia Interaktif yang meningkatkan motivasi belajar anak. Kesimpulan dari penelitian ini menunjukan bahwa perancangan dan pembuatan Multimedia Interaktif telah melalui tahap uji kelayakan. Hasil uji kelayakan menyatakan bahwa media ini valid dan reliabel untuk dimanfaatkan secara menyeluruh dalam pembelajaran tematik terpadu di sekolah dasar.

Penerapan CD Multimedia Interaktif berbasis PBL yang diterapkan di SD Islam Modern YAAK Ampang Kuranji menunjukkan efektivitas penggunaan media pembelajaran Multimedia Interaktif berbasis PBL pada pembelajaran Tematik Terpadu pada tema 8. Lingkungan sahabata kita, sub tema manusia dan lingkungan. Berdasarkan hasil percobaan diketahui melalui aktivitas siswa dan hasil belajar. Aktivitas siswa selama pembelajaran sangat baik dan hasil belajar menunjukkan hasil yang baik 


\section{KESIMPULAN}

Dihasilkan media pembelajaran Multimedia Interaktif pada pembelajaran Tematik Terpadu dengan Model PBL di Kelas V Sekolah Dasar kategori sangat valid. Hal ini dapat dilihat berdasarkan hasil validasi bahan ajar oleh validator ahli dan praktisi pendidikan yang telah dilaksanakan, baik pada RPP dan media interaktif yang dikembangkan. Multimedia Interaktif dikatakan praktis dilihat dari keterlaksanaan bahan ajar dan RPP oleh observer terhadap guru yang mengajar dengan kategori sangat praktis. Multimedia Interaktif dikatakan fektiv pada penelitian ini dilihat dari aktivitas siswa dan hasil belajar.

\section{REFERENSI}

Taufik Taufina \& Arwin. (2018). PENINGKATAN SIKAP DAN KEMAMPUAN BERPIKIR ILMIAH SISWA MELALUI MODEL PBL DI SEKOLAH DASAR. Jurnal Basicedu Volume 4 Nomor 2 April 2020 Hal. 491 - 497 JURNAL BASICEDU Research \& Learning in Elementary Education Https://jbasic.org/index.php/basicedu, 4(2), 491-497.

Abidin, Yunus. (2014) Desain Sistem Pembelajaran Dalam Konteks Kurikulum 2013. Bandung: PT Refika Aditama

Maharani, Putri.(2018). Pengembangan Multimedia Pembelajaran Interaktif Menggunakan Contruct 2 Tentang Suhu dan Kalor untuk Siswa Kelas X SMA. Lampung: Universitas Islam Negeri Raden Intan Lampung

Majid, Abddul. (2014). Perencanaan Pembelajaran Mengembangkan Standar Kompetensi Guru.Remaja Rosdakarya. Bandung

Sugiyono. 2012. Metode Penelitian Pendidikan. Bandung: Alfabeta
Taufik, T dan Silfi Melindawati. (2016). Pengembangan Bahan Ajar Tematik Terpadu dengan Model Problem Based Learning di Kelas IV Sekolah Dasar. EJurnal- ESJ VOLUME 5, NO. 1, JUNI 2016

Taufik, T dan Rahmi, Y. (2018). Meningkatkan Membaca Pemahaman Menggunakan Metode Genering Interacting Schemata and Text (GIST) diSekolah Dasar. E-Jurnal Pembelajaran Inovasi, Jurnal Ilmiah Pendidikan Dasar. 6 (1), 2018.

Taufik, T dan Zainarlis, Z. (2018). Peningkatan Keterampilan Membaca Pemahaman dengan Menggunakan Takling Stick Di Kelas IV SDN 37 Koto Pulai. E-Jurnal Pembelajaran Inovasi, Jurnal Ilmiah Pendidikan Dasar. 6 (1), 2018.

Taufik, T dan Arwin, A. (2018).Efektivitas Strategi Reciprocal Teaching dan KWL Terhadap Keterampilan Membaca Pemahaman Siswa Sekolah Dasar. E-Jurnal Pembelajaran Inovasi, Jurnal Ilmiah Pendidikan Dasar. 6 (1), 2018.

Taufina Taufik, dkk.(2018). Pengaruh Strategi Question Answer Relationship Terhadap Keterampilan Membaca Pemahaman Siswa Sekolah Dasar. E-Jurnal Pembelajaran Inovasi, Jurnal Ilmiah Pendidikan Dasar. 6 (1), 2018.

Taufik Taufina.(2016). Peningkatan Keterampilan Berbicara dengan Menggunakn Media Film Strip di Kelas II Sekolah Dasar Percobaan Kota Padang. E-Jurnal Pembelajaran Inovasi, Pedagogi.12 (1), 25-35,2016

Taufina \& Damris, Sanjaya. 2019. Peningkatan Hasil Belajar Pembelajaran Tematik Terpadu Menggunakan Model PBL di Kelas V Sekolah Dasar. E-Jurnal Pembelajaran Inovasi, Pedagogi. Vol.8 No.2,2019.

Taufina \& Wahyuni Oktalativa. Peningkatan Proses Pembelajaran Tematik Terpadu Menggunakan Model Problem Based Learning pada Kelas V Sekolah Dasar. EJurnal Pembelajaran Inovasi, Jurnal Ilmiah Pendidikan Dasar. Vol.8 (1), 2020. 
946 Pengembangan Multimedia Interaktif Berbasis Model Problem Based Learning (PBL) Untuk Siswa Kelas V Sekolah Dasar di SD Islam Modern Yaak Dharmasraya - Rahmadani, Taufina

DOI:_https://doi.org/10.31004/basicedu.v4i4.465

Taufina. 2016. Mozaik Keterampilan Berbahasa di Sekolah Dasar. Bandung: Angkasa Bandung.

Taufina dan Faisal. 2016. Mozaik Penilaian Pembelajaran Bahasa dan Apresiasi Sastra Indonesia. Bandung: Angkasa Bandung.

Taufina dan Chandra. 2017. Developing The Big Questions And

Sanjaya, Rangga. (2016). Multimedia Interaktif Pelatihan Service Excellent Menggunakan Pendekatan Story Based Learning.Jurnal Informatika, Vol.Iii No.1 April 2016

Setyaningsih, Agus. (2017). Pengembangan Media Pembelajaran Tematik Sub Tema Tubuh Manusia Berbasis Adobe Flash CS6 Kelas V SD/MI.Yogyakarta: Universitas Negeri Sunan Kalijaga

Sholikhah, dkk.(2017). Penggunaan Media Interaktif Berbasis Saintifik untuk Meningkatkan Keterampilan Bercerita Wayang pada Siswa Sekolah Dasar.Jurnal Dikdatika Dwija Indria ISSN:2337-8786 